\title{
Treatment of high fracture of the neck of the mandibular condylar process by rigid fixation performed by lag screws: Finite element analysis
}

\section{Leczenie wysokiego złamania szyjki wyrostka kłykciowego żuchwy poprzez sztywne unieruchomienie śrubami - analiza z wykorzystaniem elementów skończonych}

\author{
Marcin Kozakiewicz, ${ }^{1, A, C-F}$, Jacek Świniarski2,A-C,E,F \\ ${ }^{1}$ Department of Maxillofacial Surgery, Medical University of Lodz, Łódź, Poland \\ 2 Department of Strength of Materials and Structures, Technical University of Lodz, Łódź, Poland \\ A - research concept and design; $\mathrm{B}$ - collection and/or assembly of data; $\mathrm{C}$ - data analysis and interpretation; \\ $D$ - writing the article; $E$ - critical revision of the article; $F$ - final approval of article
}

Address for correspondence

Marcin Kozakiewicz

E-mail:marcin.kozakiewicz@umed.lodz.pl

\section{Funding sources}

Grant by the Medical University of Lodz, Poland

(1.503/5-061-02/503-51-001).

Conflict of interest

none declared

Received on June 04, 2017

Revised on July 03, 2017

Accepted on July 14, 2017

D0I

$10.17219 / \mathrm{dmp} / 75907$

Copyright

○ 2017 by Wroclaw Medical University

and Polish Dental Society

This is an article distributed under the terms of the

Creative Commons Attribution Non-Commercial License

(http://creativecommons.org/licenses/by-nc-nd/4.0/)

\begin{abstract}
Background. From 1 to 4 fixing screws can be used clinically for rigid fixation of a mandibular condyle fracture, but contrarily, there is an opinion that insertion of even 3 screws in this region is technically impossible. On the other hand, the application of a single screw is the simplest technique. But if it is rigid?

Objectives. Evaluation of the rigidity of titanium lag screw fixation in a mandible high condyle neck fracture.

Material and methods. A numerical analysis was performed using a model of a high condylar neck fracture. Fixation by 1, 2 or 3 lag screws were tested. The equivalent stress (S) distribution and displacement (D) of the fracture fragments were calculated.

Results. $\mathrm{S}=464 \mathrm{MPa}$ in 1-screw fixation and was spread widely in the condylar head (137 MPa) and downward in the distal mandibular fragment. In the 2-screw fixation, the anterior screw was more stressed $(S=319 \mathrm{MPa}$ ). Stress concentration in the condylar head was observed around the anterior screw $(211 \mathrm{MPa})$ and spread toward the sigmoid notch in the distal bone fragment. The best biomechanical situation was in the 3-screw fixation ( $S=222 \mathrm{MPa}$ ). The area of stress in the condylar head was limited and low (108 MPa), and the distribution of equivalent stress in the rest of the mandible was close to normal during mastication. Normal bone elasticity presented in the condyle neck was $9.6 \pm 3.7 \mu \mathrm{m}$ during the occlusal load. In 1 screw $D=558 \pm 245 \mu \mathrm{m}$, for 2 screws $D=218 \pm 81 \mu \mathrm{m}$, and for the 3 -screw fixation $\mathrm{D}=217 \pm 144 \mu \mathrm{m}$. Two and 3 screw fixations were statistically better than the $1 \mathrm{screw}$ rigid fixation $(p<0.001)$.
\end{abstract}

Conclusions. Open fixation by two $2.0 \mathrm{~mm}$ diameter lag screws is sufficiently rigid. The use of more screws seems to be unnecessary.

Key words: fracture, lag screw, mandibular condyle, rigid fixation

Słowa kluczowe: złamanie, Śruba, wyrostek kłykciowy żuchwy, unieruchomienie sztywne 
Fractures of the mandible are the most common injuries in maxillofacial traumatology and its condyle fracture is the most frequent one. ${ }^{1}$ As far as treatment is concerned, mandibular condyle fractures are still treated conservatively. ${ }^{2}$ However, open internal rigid fixation (ORIF) treatment allows restoration of vertical ramus height, i.e. prevention of occlusal disorders, anatomical position of the bone fragments and the disc, physiological function of the disk and condyle ${ }^{3}$ as well as that of the lateral pterygoid muscle that allows immediate functional movement of the jaw, avoids ankylosis of the temporomandibular joint induced by trauma and yields a pain-free result for the patient. ${ }^{4,5}$ Several techniques have been proposed to reduce and fix the fractures, such as standard bone screws and plates and a long lag screw, by promising biomechanical fixation. ${ }^{6-11}$ On one hand, the highest neck fractures (just lower than a C-head fracture ${ }^{12}$ ) extend below the condylar head, leaving a small neck fragment connected to the head that enables the possible application of lag or positioning screws (Fig. 1), or on the other hand, the application of a dedicated plate. Investigation of the first fixation technique is the subject of this study, due to its high effectiveness $^{13}$. The second issue is how many screws should be applied. One, 2 or 3 fixing screws can be used clinically (Fig. 2). There is the opinion that insertion of 3 screws in this region is technically impossible. ${ }^{6}$

Also, studies on the use of bioresorbable osteosynthesis materials for condyle fractures should be mentioned. ${ }^{14-17}$ They lead to the conclusion that resorbable materials do not yet seem as strong as titanium ones. Titanium alloy seems to be the only available material that can bear occlusal loading. ${ }^{14,17}$ The only exception is a result obtained by Xin's ${ }^{18}$ team in finite element numerical simulation, but there the maximal equivalent stress observed in 2-screw type B head fracture fixation was as low as only $2.8 \mathrm{kPa}$ per screw, which would allow for the application of any kind of polymeric long screw. But comparing to other papers ${ }^{14,15}$ it seems to expose their numerical model limitations.

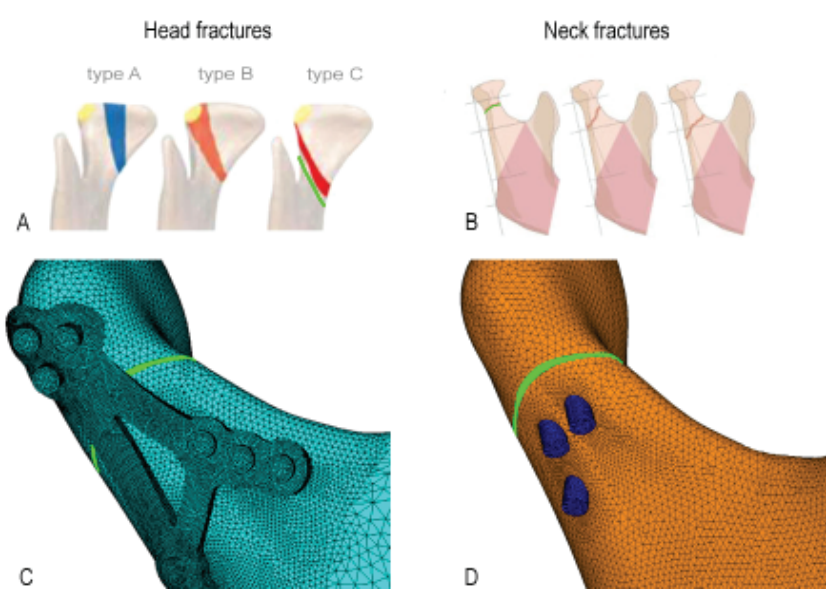

Fig. 1. The high condylar neck fracture examined in this study is located just below the head fracture type C [35] marked by a green line in the top left (A) and marked in line with the highest neck fracture (B) in the top right [10], and below: C - ORIF by dedicated plate [31], D - ORIF by headless bone screws [25]
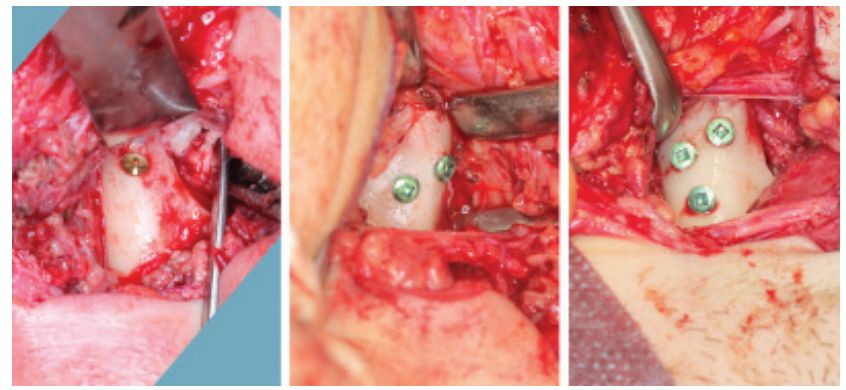

Fig. 2. Open rigid internal fixation of condylar head fracture. The injury can be fixed by 1, 2 or 32.0 lag screws. Application of 1 screw is the simplest way. Three-screw insertion is the surest

The objective of this study was the evaluation of the rigidity of titanium lag screw fixation in a mandible high condyle neck fracture.

\section{Material and methods}

The design of a screw of 16-mm length combined with a diameter of $2.0 \mathrm{~mm}$ was used in this study. The lag screw was designed to possess the top $40 \%$ of its length covered by the thread, and the remaining part of the shaft was smooth. A high condylar neck fracture was fixed with stabilization by 1, 2 or 3 lag screws made of medical titanium alloy grade 5 (Ti6Al4V). The Young's modulus and Poisson coefficient were 104 GPa and 0.3, respectively. The screws were applied to the right-hand side of the mandible.

The boundary conditions (Fig. 3) were based on the series of previous studies. ${ }^{19-22}$ The loads were applied for a mouth minimally interincisal open $(5 \mathrm{~mm})^{19}$ that induces the most stress in the condyle. Five main muscle force and action directions were developed according to the literature: ${ }^{20,21}$ main temporalis action: $\mathrm{X}=0.064 \mathrm{~N}, \mathrm{Y}=0.37 \mathrm{~N}, \mathrm{Z}=-0.13 \mathrm{~N}$ and medial temporal action: $\mathrm{X}=0.97 \mathrm{~N}, \mathrm{Y}=5.68 \mathrm{~N}, \mathrm{Z}=-7.44 \mathrm{~N}$, deep masseter action: $X=7.776 \mathrm{~N}, \mathrm{Y}=127.23 \mathrm{~N}$, $Z=22.68 \mathrm{~N}$, superficial masseter action: $\mathrm{X}=12.873 \mathrm{~N}$, $\mathrm{Y}=183.5 \mathrm{~N}, \mathrm{Z}=12.11 \mathrm{~N}$, action of medial pterygoid: $\mathrm{X}=140.38 \mathrm{~N}, \mathrm{Y}=237.8 \mathrm{~N}, \mathrm{Z}=-77.3 \mathrm{~N}$. The force and direction were based on magnetic resonance data of humans. ${ }^{19}$ The models used tetrahedral linear elements with 3,200,000 degrees of freedom. The nonlinear strain solver and material properties were linear. Dentition in such models had no biomechanical value according to the literature, ${ }^{19,21}$ thus it was omitted. The cortical bone Young's modulus $14.7 \mathrm{GPa}$, cancellous bone $0.7 \mathrm{GPa}$ and a Poisson coefficient of 0.3 were used according to experimental validations. ${ }^{21-23}$ Assumptions for fracture were:

1) the high condylar neck fracture (AO classification code: 91P.m.N0) ${ }^{12}$ was fixed with 1, 2 or 3 lateral oblique lag screws (Fig. 4-5),

2) the gap between bone segments was $0.32 \mathrm{~mm}$, 


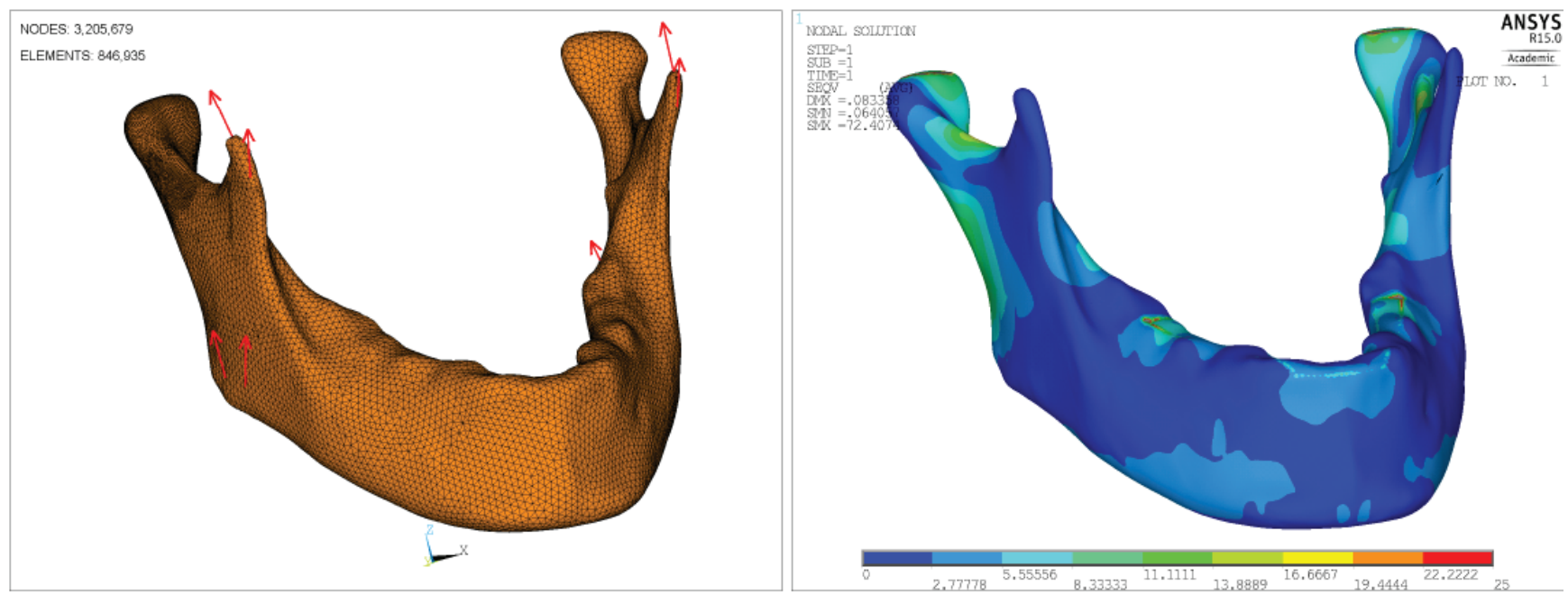

Fig. 3. Reference model and loading configuration (vectors of faces applied). Normal stress (compression and traction) distribution in the mandible after occlusal load
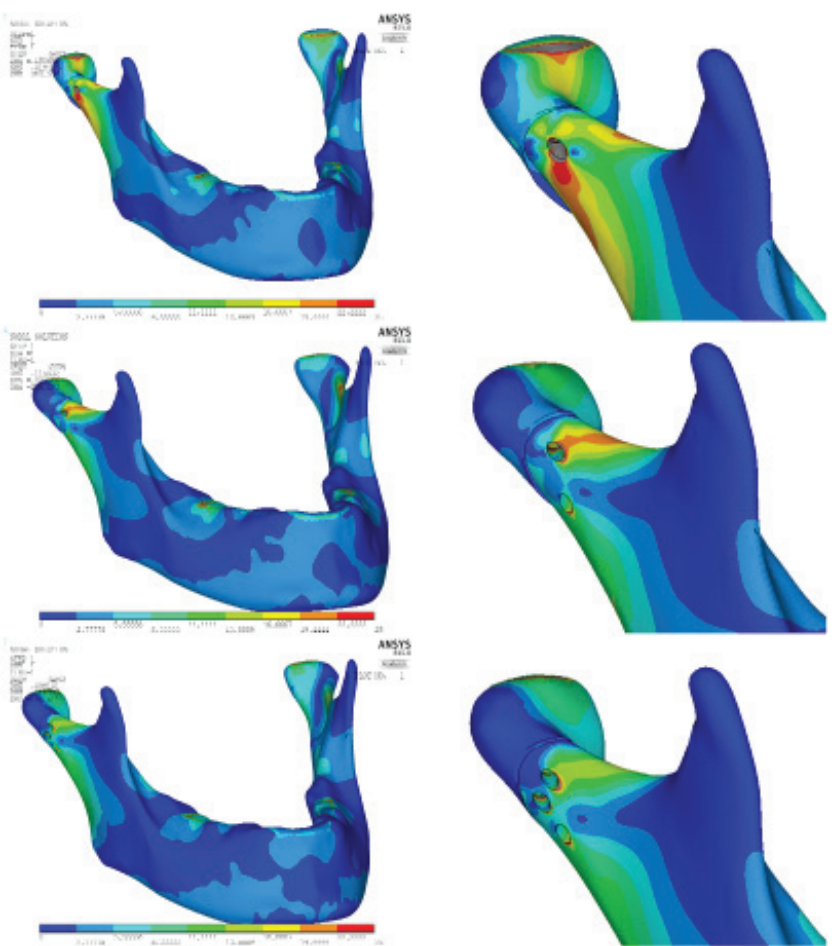

Fig. 4. Model and general biomechanical solutions for $2.0 \mathrm{~mm}$ lag screws. Global (left) and local results (right). Condyle high neck fracture reduced and fixed by one lag screw after occlusal load presents maximum equivalent stress. Stress propagation in the mandible bone - right: bidirectional spreading of the stress in the condyle neck in the case of one lag screw (top); the stress travels anteriorly to the sigmoid notch in the case fixed by two lag screws (middle). Three lag screw fixation (bottom) is similar to the reference distribution (Figure 3 ) of an unaffected mandible (the most rigid fixation)
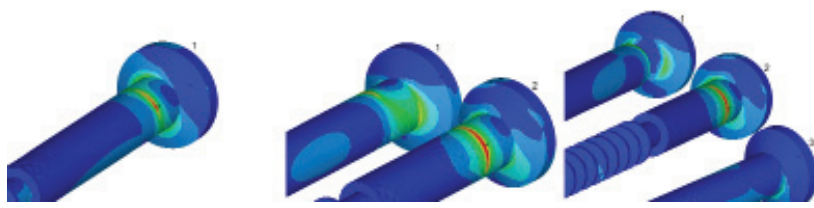

Fig. 5. Stress distribution in screws. The maximum stress is at the site of bone segment contact in the single screw modality just below the screw head (434 MPa). The second screw takes the maximum stress, but when two screws are applied, it is much less than in the one screw fixation (319 MPa). In the three-screw case, the second screw still has the highest stress, but it is less than in the previous case load (222 MPa)
3) the contact between the screws and bony segments was defined as a bonded type in the threaded region and a sliding one in the non-threaded screw core (lag screw action),

4) the contact between the surfaces of the 2 segments was defined according to Xin. ${ }^{18}$

The study was done in Ansys ${ }^{\circledR}$ R14.5 (Ansys, Inc., Canonsburg, USA). The stress and displacement in the fracture line were analyzed on the external surface of the mandible as well as on both surfaces of the fracture fissure. After loading, the distance between fracture fragments increased in all 3 fixation methods. A Kruskal-Wallis test was performed. The method of fixation was established as the factor and relative displacement of fracture fragments as the dependent variable. Statgraphics Centurion XVI (Statpoint Technologies, Inc., Warrenton, Virginia, USA) was used, and statistical significance was indicated by $\mathrm{p}<0.05$.

\section{Results}

After occlusal loading, calculations revealed in a normal mandible (Fig. 3) a maximum stress of $\sigma_{\text {red } \max }=72 \mathrm{MPa}$ located in the alveolar ridge. On one hand, the stress in the condyle region can be described as a response to a muscular force in the glenoid fossa, and on the other hand, as compression (in the posterior border) and traction (in the sigmoid notch). Thirteen megapascals of compression were observed in the posterior part of the ascending ramus, with a maximum at half of the height. A higher equivalent stress, approx. $25 \mathrm{MPa}$, was detected in the traction region, i.e. the sigmoid notch. The regional maximum was located there in the subtle medial aspect.

All fracture models fixed by lag screws (Fig. 4-5) demonstrated that after loading, the distribution of stress was concentrated in the most anterior screw. Distribution of the equivalent stress according to the Huber-Hencky-von Mises theory of the FEA model of the mandible affected 
with a high condylar fracture revealed the following maximum equivalent stress in the bone: $364 \mathrm{MPa}, 226 \mathrm{MPa}$ and $197 \mathrm{MPa}$ for 1- 2- and 3-2.0 mm-screw stabilization, respectively (Fig. 4). The maximum equivalent stress $\sigma_{\text {red } \max }=464 \mathrm{MPa}$ in 1-screw fixation (located in the screw material) was spread widely in the condylar head $\left(\sigma_{\text {red }}=137 \mathrm{MPa}\right)$ and downward in the distal (i.e. main) mandibular fragment.

Mechanical improvement was noticed in the 2-screw fixation. The lower screw was more stressed but in a decreased amount $\left(\sigma_{\text {red } \max }=319 \mathrm{MPa}\right)$ compared to 1 -screw fixation. Stress concentration in the condylar head was observed around the lower screws $\left(\sigma_{\text {red }}=211 \mathrm{MPa}\right)$ and spread towards the sigmoid notch in the distal fragment. The most valuable biomechanical situation among the tested models was the 3-screw fixation of the fracture. It was only $\sigma_{\text {red } \max }=222 \mathrm{MPa}$ located in the lowest screws in the inferior aspect. The area of stress in the condylar head was limited and small $\left(\sigma_{\text {red }}=108 \mathrm{MPa}\right)$, and the distribution of the equivalent stress in the rest of the mandible was close to normal unaffected bone during mastication.

Normal bone elasticity present in the condyle neck was $9.6 \pm 3.7 \mu \mathrm{m}$ during an occlusal load (Fig. 3). It had the lowest displacement among all the tested models, with high significance $(\mathrm{p}<0.001)$. The mean relative displacement of fracture fragments along the fracture line with 1 screw applied for ORIF was $558 \pm 245 \mu \mathrm{m}$, while for 2 screws, the displacement was $218 \pm 81 \mu \mathrm{m}$, and for 3 screws, it was $217 \pm 144 \mu \mathrm{m}$. Detailed 4 direction displacement is shown in Table 1 and Fig. 6. Thus, the one screw fixation was the worst method for facture stabilization. Both 2- as well as 3-screw fixations were similarly efficient stabilization methods. Moreover, both 2- and 3-screw fixations were statistically better than 1-screw rigid fixation (test statistic $=23.69, \mathrm{p}<0.001)$.

\section{Discussion}

First, it should be noted that "there is no defined anatomic border line between the condylar neck and the condylar head" ${ }^{12}$ This can lead to the intuitive classification of all fractures that are fixed by lag/positioning screws as head fractures, but there are neck fractures that can be osteosynthesized with plates or lag screws (Fig. 1). A fracture "re-

Table 1. Mean relative displacement during occlusal loading in fracture fissure after rigid fixation of high condylar neck fracture by lag screws. Reference describes normal condyle neck bone elasticity during biting

\begin{tabular}{|l|c|c|c|c|}
\hline \multirow{2}{*}{$\begin{array}{l}\text { Location of } \\
\text { measurement }\end{array}$} & \multicolumn{2}{|c|}{ Number of applied lag screws } & \multirow{2}{*}{ Reference } \\
\cline { 2 - 4 } & one & two & three & \\
\hline Anterior $(\mu \mathrm{m})$ & 267 & 209 & 195 & 8 \\
Lateral $(\mu \mathrm{m})$ & 313 & 213 & 77 & 17 \\
Posterior $(\mu \mathrm{m})$ & 1041 & 336 & 479 & 7 \\
Medial $(\mu \mathrm{m})$ & 530 & 76 & 77 & 5 \\
\hline
\end{tabular}

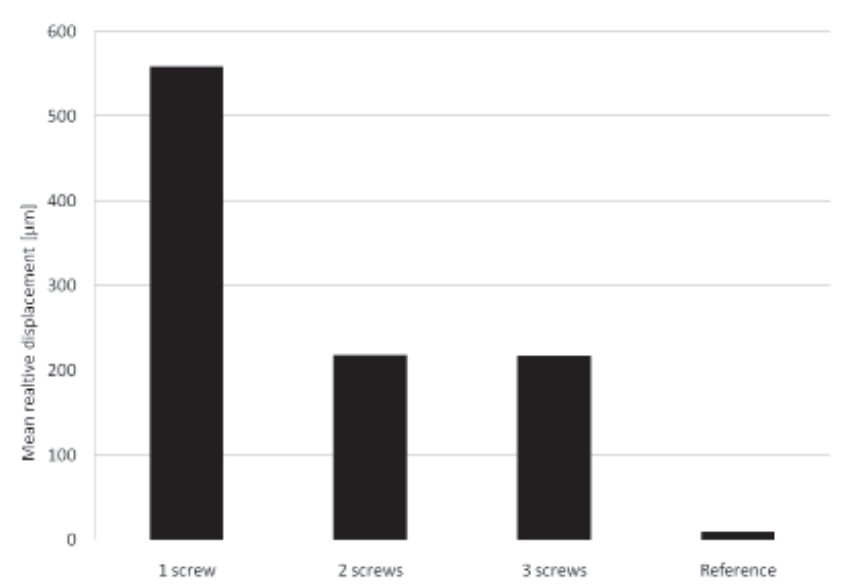

Fig. 6. Mean relative displacement between fracture fragments in the series of studied internal fixation

maining caudal to the condylar head reference line" is a neck fracture. ${ }^{12}$ That important line is located just below the "bony substance of the lateral condylar head" pole zone, ${ }^{12}$ and fractures located below can be fixed by lag screws.

Surgical interventions using mini-plate osteosynthesis and a lag screw can be used for fixation of condyle fractures. Surgical osteosynthesis is especially recommended in patients with high condylar fractures or dislocated fractures to achieve ideal anatomy and function. ${ }^{9,24-27}$ Ideas for rigid internal fracture fixation in the condylar area (base, low neck, high neck, and head) have significantly changed in the last decade ${ }^{25-29}$ but the issue of optimal stabilization of the reduced fracture remains unclear because even classical fixations can have unknown biomechanical (mathematical) solutions, ${ }^{30}$ and moreover some authors suggest that 3 lag screws with $2.0 \mathrm{~mm}$ diameters are impossible to insert in to a condyle fracture. ${ }^{6}$ Thus, the topic of condylar fracture osteosynthesis remains highly controversial and challenging.

The major principle in all fracture treatments is perfect reduction, but generally, it cannot be maintained post-operationally without suitable fixing materials. ${ }^{14}$ Fractures of fixing materials have been described in the literature. ${ }^{31}$ It is hypothesized that the main reason is improper reduction. ${ }^{32}$ Lag screw fixation is very stable ${ }^{7}$ and reduction is much simpler compared to plate application. Thus, reduction and fixation are involved with each other. Therefore, the crucial issue is how to achieve reduction and fixation effectively in high condylar fractures. It has been possible to avoid complications and achieve proper results in the treatment of fractures of the mandibular condyle by applying lag screws as individual anatomical characteristics are considered $^{32}$ and application of screws are appropriate for the occlusal load. ${ }^{14}$ Previously, titanium screws with diameters of $2.0 \mathrm{~mm}, 1.7 \mathrm{~mm}$ and $1.2 \mathrm{~mm}$ were tested in their physiological limits, ${ }^{14}$ and the smallest one was rejected as material that was not capable of bearing occlusal loadings up to $200 \mathrm{~N}$, while there is no doubt that the $2.0 \mathrm{~mm}$ system is adequate for fixation. 
With lag screw application, it has been shown that the major factor in the extent of the trauma relating to surgical access was the reduction of fracture fragments. The method ensured stable fixation of the fracture with a minimum amount of osteosynthesis material while reducing the operative time; ${ }^{33}$ this was confirmed by computerized tomography and magnetic resonance imaging. ${ }^{4}$ Lateral lag screw insertion and articular disk reduction are mandatory in anatomical and functional recovery of the temporomandibular joint in patients with condylar process fractures. ${ }^{4,10}$ Moreover, lag screws can be more easily removed after 3 months of healing than can a plate, due to the lack of need of a wide surgical approach. These metal parts should be removed from the body of the patient because of possible soft tissue irritation and consequential bone resorption. Thus, in border cases (high neck fracture/type $C$ head fracture) where lag screw or plates have possible applications, the lag screw is the better choice.

The biomechanical results obtained in this study present satisfactory control of stress propagation in the region surrounding the fracture line after lag screw fixation. The thinnest bone is located in the lateral part of the distal bone fragment, i.e. the closest distance between the condyle bone surface and the screw, but it is within safety limits (minimum $3 \mathrm{~mm}$ of cortical bone). Furthermore, in the distal bone fragment, the highest stress is located on the medial side.

After application of 3 lag screws, high condylar neck fracture fragments can be reduced properly. As was previously mentioned, ${ }^{20,34}$ the difference between the rigidity of fixation in plated cases can be explained as the dependence on a number of fixing screws in the proximal fragment (i.e. condylar head). The 2-screw modality is the weakest method for fracture fixation, while 3-screw is better and 4-screw is the strongest rigid fixation by a plate. In contrast, the application of 2 lag screws is nearly the same as 3 lag screws as far as bone fragment displacement is considered. This can be explained by the number of the remaining screws in the case of plates. In contrast to a lag screw, where there is a maximum of 3 screws, there are many fixing points in a plate screwed to the distal fragment. Moreover, bearing all this in mind, it would be better if one could apply longer screws in the proximal fragment. The thickness of bone in the distal fragment (especially in the sigmoid notch region) does not permit using screws longer than $6 \mathrm{~mm}$ in length, but it is worth using longer screws in the proximal fragment or, even better, the lag/ headless screw if possible. ${ }^{28,33}$

The application of 1 lag screw gives very rigid fixation compared to even a very stiff plate. ${ }^{34-36}$ Experience with $15 \mathrm{~mm}$ or $17 \mathrm{~mm}$ lag screws showed that two $2.0 \mathrm{~mm}$ lag screws were enough for stable osteosynthesis, but a single screw was not adequate because of its inability to eliminate the rotation of reduced bone fragments. ${ }^{37}$ The main advantages of lag screw fixation are the greatest stability, short surgery duration and reduced articular scarifica- tion. The usage of mini-plate requires a wider surgical approach, denudes a bigger bone surface and is more complicated surgically. Moreover, the morbidity to soft tissue is lower in the lag screw applications. ${ }^{18}$ In contrast to long, all-length-threaded positioning screws that can maintain the spacing between bone segments, a lag screw has the advantage of tightening bone segments to each other.

On one hand, increasing the fixing screw number improves the rigidity of bone fragments, ${ }^{37}$ (Fig. 4 and Table 1), but on the other hand, it makes the technical aspect of surgery more complex. It is possible to damage bone iatrogenically when the operator is trying to install the $3^{\text {th }}$ lag screw. For the best mechanical advantage, in the opinion of the authors of this study, the application of $22.0 \mathrm{~mm}$ lag screws provides rigidity and prevents rotation of the proximal fragment.

Surprisingly, utilization of lag screws is not as frequent as its effectiveness would indicate; it is used in only $6 \%$ of all mandibular fractures. ${ }^{13}$ The first reason is most likely that it requires a more difficult choice in angulation compared to simple short plating screws and possibly indicates a low faith in the rigidity produced by only a few fixation screws.

\section{Conclusions}

Open fixation in a high condylar neck fracture by $22.0 \mathrm{~mm}$ diameter lag screws is appropriately rigid. The use of 3 screws is possible but gives only minimal improvements, and the clinical application is much more difficult than that with 2 screws; thus, such fixation seems unnecessary.

\section{References}

1. Puch A, Kurczyński M, Arkuszewski P, Bogusiak K. Overview of emergency department visits in Craniomaxillofacial and Oncological Clinic of Medical University in Lodz. Dent Med Probl. 2016;53:244-252.

2. Bergh B, Blankestijn J, Ploeg T, Tuinzing DB, Forouzanfar T. Conservative treatment of a mandibular condyle fracture: Comparing intermaxillary fixation with screws or arch bar. A randomised clinical trial. J Craniomaxillofac Surg. 2015;43:671-676.

3. Loster JE, Wieczorek A, Ryniewicz WI. Condylar guidance angles obtained from panoramic radiographic images: An evaluation of their reproducibility. Dent Med Probl. 2017;54:35-40.

4. Kolk A, Neff A. Long-term results of ORIF of condylar head fractures of the mandible: A prospective 5-year follow-up study of smallfragment positional-screw osteosynthesis (SFPSO). J Craniomaxillofac Surg. 2015;43:452-461.

5. Li ZB. Condylar fractures, disc injury and development of temporomandibular joint ankylosis: discussion on the related problems. Zhonghua Kou Qiang Yi Xue Za Zhi. 2009;44:728-730.

6. Zrounba H, Lutz JC, Zink S, Wilk A. Epidemiology and treatment outcome of surgically treated mandibular condyle fractures. A five years retrospective study. J Craniomaxillofac Surg. 2014;42:879-884.

7. Krenkel C. Axial 'anchor' screw (lag screw with biconcave washer) or 'slanted-screw' plate for osteosynthesis of fractures of the mandibular condylar process. J Craniomaxillofac Surg. 1992;20:348-353.

8. Neff A, Kolk A, Deppe H, Horch HH. Neue Aspekte zur Indikation der operativen Versorgung intraartikularer und hoher Kiefergelenkluxations frakturen. Mund Kiefer Gesichtschir. 1999;3:24-29 (in German). 
9. Rasse M. Neuere Entwicklungen der Therapie der Gelenkfortsatzbruche der Mandibula. Mund Kiefer Gesichtschir. 2000;4:69-87 [in German].

10. Xu X, Ping YF, Yan JL. Application of lateral lag screw with sagittal condylar fracture and management of articular disk. Zhejiang $\mathrm{Da}$ Xue Xue Bao Yi Xue Ban. 2008;37:519-523.

11. Li Z, Li ZB. Reduction and screw fixation of condyle sagittal fracture. Zhonghua Kou Qiang Yi Xue Za Zhi. 2009;44:709-712.

12. Neff A, Cornelius CP, Rasse M, Torre DD, Audigé L. The Comprehensive AOCMF Classification System: Condylar Process Fractures - Level 3 Tutorial. Craniomaxillofac Trauma Reconstr. 2014;7(Suppl 1): S044-S058.

13. Bormann $\mathrm{KH}$, Wild S, Gellrich NC, et al. Five-year retrospective study of mandibular fractures in Freiburg, Germany: incidence, etiology, treatment, and complications. J Oral Maxillofac Surg. 2009;67:1251-1255.

14. Neff A, Mühlberger G, Karoglan M, et al. Stabilität der Osteosynthese bei Gelenkwalzenfrakturen in Klinik und biomechanischer Simulation. Mund Kiefer GesichtsChir. 2004;8:63-74 [in German].

15. Schneider M, Eckelt U, Reitemeier B, et al. Stability of fixation of diacapitular fractures of the mandibular condylar process by ultrasound-aided resorbable pins (SonicWeld $\mathrm{Rx}(\mathrm{R})$ System) in pigs. Br J Oral Maxillofac Surg. 2011;49:297-301.

16. Schneider $M$, Seinige $C$, Pilling $E$, et al. Ultrasound-aided resorbable osteosynthesis of fractures of the mandibular condylar base: an experimental study in sheep. Br J Oral Maxillofac Surg. 2012;50:528-532.

17. Suzuki T, Kawamura H, Kasahara T, Nagasaka H. Resorbable poly-L-lactide plates and screws for the treatment of mandibular condylar process fractures: A clinical and radiologic follow-up study. J Oral Maxillofac Surg. 2004;62:919-924.

18. Xin P, Jiang B, Dai J, et al. Finite element analysis of type B condylar head fractures and osteosynthesis using two positional screws. J Craniomaxillofac Surg. 2014;42:482-488.

19. Mesnard M, Ramos A, Lokhov VA, Ballu A, Nyashin Yi, Simfies JA. Muscular and articular forces exerted on the mandible. In: $1^{\text {st }}$ International conference on biodental engineering. Porto, Portugal: CRC Press (Taylor 8 Francis), 2010;199-204.

20. Iwasaki LR, Baird BW, McCall Jr WD, Plickel JC. Muscle and temporomandibular joint forces associated with chin cup loading predicted by numerical modeling. Am J Orthod Dentofacial Orthop. 2003;124:530-540.

21. Ramos A, Completo A, Relvas C, Mesnard M, Simoes JA. Straight semianatomic and anatomic TMJ implants: The influence of condylar geometry and bone fixation screws. J Cran Maxillofac Surg. 2011;39:343-350.

22. Motoyoshi M, Ueno S, Okazaki K, Shimuzi N. Bone stress for a mini implant close to the roots of adjacent teeth - 3D finite element analysis. Int J Oral Maxillofacial Surg. 2009;38:363-368.

23. Ichim I, Kieser JA, Swain MV. Functional significance of strain distribution in the human mandible under masticatory load: numerical predictions. Arch Oral Biol. 2007;52:465-473.

24. Chossegros C, Cheynet F, Blanc JL, Bourezak Z. Short retromandibular approach of subcondylar fractures: clinical and radiologic long-term evaluation. Oral Surg Oral Med Oral Pathol Oral Radiol Endod. 1996;82:248-252.

25. Eulert $\mathrm{S}$, et al. Study on treatment of condylar process fractures of the mandible. Ann Anat. 2007;189:377-383.

26. Haug RH, Gilman P, Peterson GP, Goltz M. A biomechanical evaluation of mandibular condyle fracture plating techniques. J Oral Maxillofac Surg. 2002;60:73-80.

27. Abdel-Galil K, Loukota R. Fractures of the mandibular condyle: evidence base and current concepts of management. Br J Oral Maxillofac Surg. 2010;48:520-526.

28. Schneider $M$, et al. Open reduction and internal fixation versus closed treatment and mandibulomaxillary fixation of fractures of the mandibular condylar process: A randomized, prospective, multicenter study with special evaluation of fracture level. J Oral Maxillofac Surg. 2008;66:2537-2544.

29. Aquilina P, Chamoli U, Parr WCH, Clausen PD, Wroe S. Finite element analysis of three patterns of internal fixation of fractures of the mandibular condyle. Br J Oral Maxillofac Surg. 2013;51:326-331.

30. Wagner A, Krach W, Schicho K, Undt G, Ploder O, Ewers R. A 3-dimensional finite-element analysis investigating the biomechanical behaviour of the mandible and plate osteosynthesis in cases of fractures of the condylar process. Oral Surg Oral Med Oral Pathol Oral Radiol Endod. 2002;94:678-686.
31. Eckelt U, Hlawitschka M. Clinical and radiological evaluation following surgical treatment of condylar neck fractures with lag screws. J Craniomaxillofac Surg. 1999;27:235-242.

32. Pilling E, Schneider M, Mai R, Loukota RA, Eckelt U. Minimally invasive fracture treatment with cannulated lag screws in intracapsular fractures of the condyle. J Oral Maxillofac Surg. 2006;64:868-872.

33. Kozakiewicz M, Swiniarski J. "A" shape plate for open rigid internal fixation of mandible condyle neck fracture. J Craniomaxillofac Surg. 2014;42:730-737.

34. Aquilina P, Parr WCH, Chamoli U, Wroe S. Finite element analysis of patient-specific condole fracture plate: A preliminary study. Craniomaxillofac Trauma Reconstr. 2015;8:111-116.

35. Boffano P, Benech R, Gallesio C, Arcuri F, Benech A. Current opinions on surgical treatment of fractures of the condylar head. Craniomaxillofac Trauma Reconstr. 2014;7:92-100.

36. Karoglan M, Schutz K, Schieferstein H, Horch HH, Neff A. Development of a static and dynamic simulator for osteosyntheses of the mandible. Technol Health Care. 2006;14:449-455.

37. Neff A, Kolk A, Neff F, Horch HH. Surgical vs. conservative therapy of diacapitular and high condylar fractures with dislocation. A comparison between MRI and axiography. Mund Kiefer Gesichtschir. 2002;6:66-73. 